\title{
Effects of strong government measures against tobacco in Hong Kong
}

\author{
JUDITH M MACKAY, GEOFFREY T BARNES
}

\begin{abstract}
The government of Hong Kong grasped the political nettle of control of tobacco in the early 1980s, since when a comprehensive policy of legislation, education, and puolicity, together with large increases in taxation on tobacco products, has been introduced. This has led to almost all of the population of Hong Kong having knowledge of the harmful effects of tobacco and of antismoking measures taken by the government. From 1982 to 1984 the number of people who smoked daily fell appreciably from 888300 to 744500 , a reduction of $16 \%$, while the number of teenage smokers was halved (from 22600 to 11200 ).

Government commitment is crucial in programmes against tobacco in developing countries; without it antismoking efforts are unlikely to be successful.
\end{abstract}

\section{Introduction}

Many countries have followed, at least in part, the recommendations of the World Health Organisation for controlling tobacco. Methods have varied from direct action by governments to the evecatching techniques of activist groups pioneered by BUGA-UP

Department of Medicine, United Christian Hospital, Hong Kong JUDITH M MACKAY, MB, FRCPED, deputy head of department

Health and Welfare Branch, Government Secretariat, Hong Kong GEOFFREY T BARNES, MA, deputy secretary for health and welfare

Correspondence to: Dr J M Mackay, Riftswood, 9th Milestone, 147 Clearwater Bay Road, Saikung, Kowloon. Hong Kong.
(Billboard Utilising Graffitists Against Unhealthy Promotions) in Australia.

Hong Kong is a city in South East Asia of almost five and a half million people, $98 \%$ of whom are Chinese. Life expectancy is 72 for men and 78 for women, the major causes of death being cancer (lung cancer is the most common), heart disease, and cerebrovascular and respiratory diseases. It has been calculated that smoking is responsible for $10 \%$ of deaths in Hong Kong: this is seven times as many as are caused by traffic accidents, or equivalent to seven fully laden jumbo jets crashing and killing all those on board each year.

The pattern of smoking in Hong Kong is quite different from that in Europe and North America (table I). Firstly, the total number of smokers is smaller: $744500(19 \%)$ people aged 15 and over are habitual cigarette smokers. Secondly, there is a much greater preponderance of male smokers: $663700(33 \%)$ men and only $80800(4 \%)$ women smoke compared with $38 \%$ and $33 \%$, respectively, in the United Kingdom. Thirdly, the age at which smoking starts is later: only $11200(2 \cdot 3 \%)$ teenagers claim to smoke daily and $8900(1.8 \%)$ occasionally. Fourthly, there is a preponderance of smokers in the older age group: only $7300(1.4 \%)$ women and $145900(26 \%)$ men aged 20-29 smoke compared with $40000(12 \%)$ women and $116800(45 \%)$ men over 60 .

Even after a fourfold increase in duty in the 1983 budget for fiscal reasons, the price of $70 \mathrm{p}$ for 20 cigarettes is still low by international standards. Duty paid on tobacco is estimated to be $£ 90$ million a year and makes up 3\% of total government revenue. Fortunately, Hong Kong does not produce tobacco; the government revenue from tobacco, therefore, is less substantial and the tobacco lobby less strong than they might be, and fewer than 1000 people are employed in the manufacture of tobacco products.

Seven of the top 20 spenders on advertising in Hong Kong, however, are from the tobacco industry, and $10 \%$ of all advertising in Hong Kong, amounting to $\$ 11$ million a year, is for tobacco, mostly on television. Tobacco companies are also using Hong Kong as a gateway in expanding trade with the People's Republic of China, the world's biggest market for tobacco. 
TABLE I-Cigarette smokers by age and sex (data obtained from General Household Survey, fuly 1984, compiled by Census and Statistics Department)

\begin{tabular}{|c|c|c|c|c|c|c|}
\hline \multirow[b]{2}{*}{ Age } & \multicolumn{2}{|c|}{ January-March '82 } & \multicolumn{2}{|c|}{ March '83 } & \multicolumn{2}{|c|}{ July '84 } \\
\hline & $\begin{array}{c}\mathrm{No}\left(\times 10^{3}\right) \\
(\%)\end{array}$ & $\begin{array}{c}\text { Rate }^{\star} \\
(\%)\end{array}$ & $\begin{array}{c}\text { No }\left(\times 10^{3}\right) \\
(\%)\end{array}$ & $\begin{array}{c}\text { Rate }_{(\%)}^{\star} \\
\text { (\%) }\end{array}$ & $\begin{array}{c}\text { No }\left(\times 10^{3}\right) \\
(\%)\end{array}$ & $\begin{array}{c}\text { Rate }_{(\%)} \\
(\%)\end{array}$ \\
\hline \multicolumn{7}{|c|}{ Whole population } \\
\hline $\begin{array}{l}15-19 \\
20-29 \\
30-39 \\
40-49 \\
50-59 \\
60+\end{array}$ & $\begin{array}{rr}22.6 & (2.5) \\
189.2 & (21 \cdot 3) \\
175.6 & (19 \cdot 8) \\
165.9 & (18 \cdot 7) \\
170.7 & (19 \cdot 2) \\
164.3 & (18.5)\end{array}$ & $\begin{array}{r}4 \cdot 2 \\
17 \cdot 5 \\
25 \cdot 9 \\
32 \cdot 8 \\
35 \cdot 4 \\
31 \cdot 1\end{array}$ & $\begin{array}{rr}16.7 & (2 \cdot 1) \\
158.4 & (20 \cdot 2) \\
160.9 & (20.5) \\
129.6 & (16.5) \\
157.0 & (20.0) \\
161.2 & (20.6)\end{array}$ & $\begin{array}{r}3 \cdot 4 \\
14 \cdot 1 \\
21 \cdot 5 \\
26 \cdot 9 \\
31 \cdot 2 \\
27 \cdot 8\end{array}$ & $\begin{array}{rr}11 \cdot 2 & (1 \cdot 5) \\
153 \cdot 2 & (20.6) \\
158.3 & (21 \cdot 3) \\
115.9 & (15 \cdot 6) \\
149.1 & (20.0) \\
156.8 & (21 \cdot 1)\end{array}$ & $\begin{array}{r}2 \cdot 3 \\
14 \cdot 1 \\
19 \cdot 4 \\
24 \cdot 3 \\
29 \cdot 2 \\
26 \cdot 2\end{array}$ \\
\hline Total & $888 \cdot 3(100 \cdot 0)$ & $23 \cdot 3$ & $783 \cdot 8(100 \cdot 0)$ & $19 \cdot 9$ & $744 \cdot 5(100 \cdot 0)$ & $18 \cdot 7$ \\
\hline \multicolumn{7}{|c|}{ Men } \\
\hline $\begin{array}{l}15-19 \\
20-29 \\
30-39 \\
40-49 \\
50-59 \\
60+\end{array}$ & $\begin{array}{rr}21 \cdot 7 & (2 \cdot 8) \\
181 \cdot 3 & (23 \cdot 1) \\
167 \cdot 6 & (21 \cdot 3) \\
151 \cdot 1 & (19 \cdot 2) \\
143 \cdot 8 & (18 \cdot 3) \\
120.9 & (15 \cdot 4)\end{array}$ & $\begin{array}{r}7.9 \\
32 \cdot 0 \\
45 \cdot 1 \\
53 \cdot 9 \\
56.9 \\
51 \cdot 6\end{array}$ & $\begin{array}{rr}15 \cdot 9 & (2 \cdot 3) \\
150.2 & (21 \cdot 7) \\
150.5 & (21 \cdot 7) \\
121 \cdot 1 & (17 \cdot 5) \\
134.5 & (19 \cdot 4) \\
120.0 & (17 \cdot 3)\end{array}$ & $\begin{array}{r}6 \cdot 3 \\
26 \cdot 1 \\
38 \cdot 0 \\
46 \cdot 1 \\
51 \cdot 0 \\
45 \cdot 9\end{array}$ & $\begin{array}{rr}11 \cdot 2 & (1 \cdot 7) \\
145 \cdot 9 & (22 \cdot 0) \\
153 \cdot 2 & (23 \cdot 1) \\
109 \cdot 2 & (16 \cdot 5) \\
127.4 & (19 \cdot 2) \\
116.8 & (17 \cdot 6)\end{array}$ & $\begin{array}{r}4 \cdot 6 \\
26 \cdot 0 \\
35 \cdot 5 \\
41 \cdot 5 \\
47 \cdot 7 \\
45 \cdot 5\end{array}$ \\
\hline Total & $786 \cdot 4(100 \cdot 0)$ & $39 \cdot 7$ & $692 \cdot 2(100 \cdot 0)$ & $34 \cdot 4$ & $663 \cdot 7(100 \cdot 0)$ & $32 \cdot 8$ \\
\hline \multicolumn{7}{|c|}{ Women } \\
\hline $\begin{array}{l}15-19+ \\
20-29 \\
30-39 \\
40-49 \\
50-59 \\
60+\end{array}$ & $\begin{array}{rr}0.9 & (0.9) \\
7.9 & (7.7) \\
8.0 & (7.8) \\
14.9 & (14.6) \\
26.9 & (25.4) \\
43.4 & (42.5)\end{array}$ & $\begin{array}{r}0 \cdot 4 \\
1 \cdot 5 \\
2 \cdot 6 \\
6 \cdot 6 \\
11 \cdot 7 \\
14 \cdot 8\end{array}$ & $\begin{array}{rr}0 \cdot 8 & (0 \cdot 9) \\
8 \cdot 2 & (9 \cdot 0) \\
10 \cdot 4 & (11 \cdot 4) \\
8 \cdot 5 & (9 \cdot 3) \\
22 \cdot 5 & (24 \cdot 6) \\
41 \cdot 2 & (45 \cdot 0)\end{array}$ & $\begin{array}{r}0 \cdot 3 \\
1 \cdot 5 \\
3 \cdot 0 \\
3 \cdot 9 \\
9 \cdot 4 \\
12 \cdot 9\end{array}$ & $\begin{array}{rr}7 \cdot 3 & (9 \cdot 0) \\
5 \cdot 1 & (6 \cdot 3) \\
6 \cdot 7 & (8 \cdot 3) \\
21 \cdot 7 & (26 \cdot 9) \\
40 \cdot 0 & (49 \cdot 5)\end{array}$ & $\begin{array}{r}1 \cdot 4 \\
1 \cdot 3 \\
3 \cdot 1 \\
8 \cdot 9 \\
11 \cdot 7\end{array}$ \\
\hline Total & $102 \cdot 0(100 \cdot 0)$ & $5 \cdot 6$ & $91 \cdot 6(100 \cdot 0)$ & $4 \cdot 8$ & $80 \cdot 8(100 \cdot 0)$ & $4 \cdot 1$ \\
\hline
\end{tabular}

*Proportion of total number of people in age group.

† Statistically unreliable estimates based on very few sample cases.

\section{Measures against tobacco}

In the 1960s and 1970s the government of Hong Kong introduced several restrictions on smoking in public places and public transport, established an ad hoc committee on smoking, and restricted advertising in areas under government control. Low key publicity was also introduced encouraging smokers to be considerate, and a voluntary code of practice for advertising cigarettes on television was agreed to by the tobacco companies-for example, they agreed to avoid advertising between $430 \mathrm{pm}$ and $630 \mathrm{pm}$. Consumption of tobacco per head, however, was not affected by these persuasive moves (table II).

TABL.E II-Tobacco consumption in Hong Kong per person aged 15 and over

\begin{tabular}{lccccccccc}
\hline Year & $1975-6$ & $76-7$ & $77-8$ & $78-9$ & $79-80$ & $80-1$ & $81-2$ & $82-3$ & $83-4$ \\
Consumption $(\mathrm{kg})$ & $2 \cdot 136$ & $2 \cdot 123$ & $2 \cdot 164$ & $2 \cdot 050$ & $2 \cdot 200$ & $2 \cdot 127$ & $1 \cdot 970$ & $1 \cdot 975$ & $1 \cdot 357$
\end{tabular}

By 1980 there was irrefutable evidence of the health hazards of smoking. Alarming statistics over the previous decade showed that in Hong Kong deaths from lung cancer had gone up by $92 \%$ from 949 in 1972 to 1826 in 1981. Deaths per 100000 population had increased by $53 \%$ (figure), and deaths from lung cancer as a proportion of all deaths had increased by $62 \%$. A comparable increase was seen in statistics for ischaemic heart disease. In addition, international studies on passive smoking indicated that nonsmokers were also affected.

Clear public support for introducing stronger measures was shown by a survey of public opinion in 1981. More than three quarters of those taking part in the survey were in favour of banning smoking in public transport and enclosed public places, publicising health warnings, and extending bans on advertising on television, even if this meant producing television programmes of less quality. The Fire Services Department added its support, presenting data (table III) that showed that one third of the 14505 fire accidents reported annually in Hong Kong were probably caused by careless smoking.

In view of this evidence the government recognised that stronger antismoking measures were required to warn the public more positively of the risks of cigarette smoking and to give non-smokers a greater degree of protection.

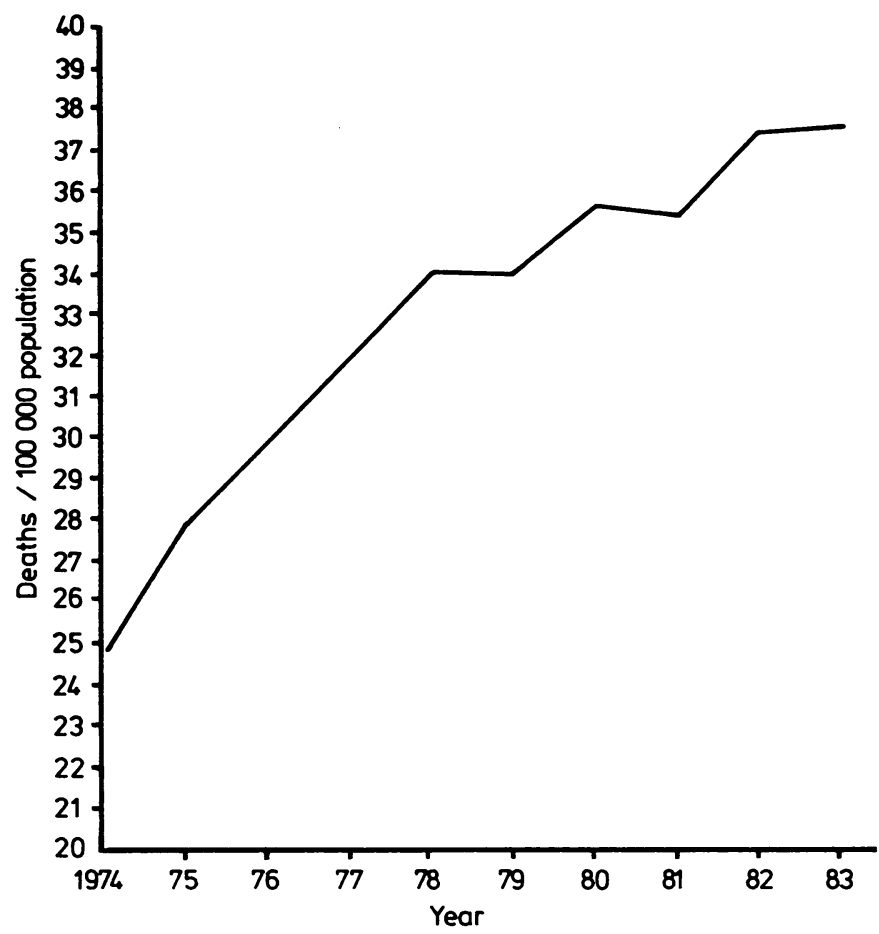

Deaths from lung cancer in Hong Kong 1974-83. Source: health and welfare branch, government secretariat.

TABLE III-Fire accidents caused by careless smoking

\begin{tabular}{|c|c|c|c|c|}
\hline \multirow[b]{2}{*}{ Year } & \multirow{2}{*}{$\begin{array}{l}\text { Total No of } \\
\text { fires from } \\
\text { all causes }\end{array}$} & \multicolumn{3}{|c|}{ Fires caused by careless disposal of smoking materials } \\
\hline & & No $(\%)$ & No of casualties & No of deaths \\
\hline 1974 & 6283 & $1474(23.5)$ & 67 & 3 \\
\hline 1975 & 7370 & $2294(31 \cdot 1)$ & 47 & 3 \\
\hline 1976 & 9383 & $3241(34 \cdot 5)$ & 72 & 2 \\
\hline 1977 & 11082 & $4031(36 \cdot 4)$ & 69 & 2 \\
\hline 1978 & $1083^{\circ}$ & $3039(28 \cdot 0)$ & 62 & \\
\hline 1979 & 13107 & $4174(31 \cdot 8)$ & 132 & 1 \\
\hline 1980 & 13213 & $4561(34 \cdot 5)$ & 87 & 2 \\
\hline 1981 & 14231 & $5102(35 \cdot 9)$ & 113 & 3 \\
\hline 1982 & 12766 & $4187(32 \cdot 8)$ & 79 & 1 \\
\hline 1983 & 14505 & $4189(28 \cdot 9)$ & 78 & \\
\hline Total & 112777 & $36292(32 \cdot 2)$ & 806 & 17 \\
\hline
\end{tabular}

Source: Fire Services Department, Hong Kong government.

\section{LEGISLATIVE MEASURES}

The Smoking (Public Health) Ordinance was enacted in July 1982 with compulsory health warnings in Chinese and English " Hong Kong government health warning: cigarette smoking is hazardous to your health"), designations of tar group on cigarette packets, and warnings on advertisements.

The government chemist carries out tests for tar and nicotine and publishes ratings twice a year. From the publication of the first results in November 1982 to November 1985 the average tar yield of each cigarette fell from $18 \mathrm{mg}$ to $15 \mathrm{mg}$ and the nicotine content from $1.4 \mathrm{mg}$ to $1.2 \mathrm{mg}$.

Smoking became prohibited in not less than half of all seats in ferries, trains, theatres, concert halls, and cinemas and was banned completely in all lifts and single decker public transport except taxis and hired vehicles, and on the lower decks of double decker buses and trams.

\section{ADMINISTRATIVE MEASURES}

Non-smoking areas were established in schools, hospitals and clinics (for doctors and other staff as well as patients and visitors), public areas in government offices, and premises dealing with food. Public health education was increased, and a major antismoking publicity campaign was launched in 1983. A comprehensive programme of measures against smoking was formulated by a government committee that included senior officials of 
government departments concerned and representatives from the medical profession. The programme was carried out in four phases: to make the community aware of the dangers of cigarette smoking; to encourage smokers to stop smoking; to discourage non-smokers, especially the young, from starting to smoke; and to promote the rights of non-smokers to a smoke free atmosphere.

The campaign made a great impact on the public through well planned publicity in the media and a wide range of supporting promotional activities held throughout the territory and at district and school levels. Exhibitions, carnivals, a mass rally, competitions to devise poster designs and slogans, and talks on control of smoking were organised.

Much emphasis was placed on educating the young. A new teaching kit describing the risks of smoking was produced and distributed to secondary schools. A school athletics meeting was held with full support from all secondary schools throughout the territory. A seminar for secondary school teachers provided them with up to date antismoking information to pass on to their students.

Doctors contributed by distributing bilingual pamphlets to patients in their surgeries, and medical organisations also showed enthusiasm, most notably the Hong Kong College of General Practitioners, which published several articles on smoking in the journal The Practitioner and helped distribute the bilingual pamphlets.

The campaign also received encouraging support from various other sectors of the community; this support was recognised by the presentation of certificates of appreciation at a public ceremony.

\section{SUCCESS}

By the end of $1983,95 \%$ of the population were not only aware of the government's publicity but also believed that smoking was harmful. The number of people who smoked daily fell dramatically from 888300 in 1982 (the first year in which statistics were collected) to 744500 in 1984 , a drop of $16 \%$ (table I). The number of men smoking decreased from $786400(40 \%)$ to $663700(33 \%)$ and the number of women from $102000(6 \%)$ to $80800(4 \%)$ These figures were confirmed by a report of the Customs and Excise department showing that from 1982 to 1983 there was a $37 \%$ decrease in cigarette imports from 5.6 to $3.5 \times 10^{\circ} \mathrm{kg}$ and a $23 \%$ decrease in locally manufactured cigarettes from $2 \cdot 1$ to $1.6 \times 10^{\prime \prime} \mathrm{kg}$. These decreases were probably due to both the tax increases and the campaign. In the age group 15-19 years the number of regular smokers halved from 22600 to 11200 between 1982 and 1984

Another sign of the campaign's success was the establishment by the tobacco industry in 1983 of the Tobacco Institute of Hong Kong Limited. The aims of the institute include the promotion of "measures calculated to benefit and protect the interests of the tobacco industry in Hong Kong."

Hong Kong's first national smoke free day, the " 1984 Smoke Out," took place in November 1984, supported by the government and for the first time, by concerned individuals in the private sector. This has now become an annual event.

\section{The future}

Three new initiatives will be of major importance for future efforts against smoking in Hong Kong.

Adiertising-The broadcasting review board, appointed by the governor, has recommended a total ban on the advertising of tobacco on television and radio. A final decision, after the views of the public have been heard, is expected in June. Submissions were made to the board by the health and welfare branch of the government and academic, medical, and other bodies, both in Hong Kong and internationally, recommending that cigarette advertising and sports sponsorship by the tobacco industry be banned from television in Hong Kong. The British Medical Association's publication Cigarette Advertising and Smoking: A Review of the Evidence by Dr Simon Chapman, summarising all the arguments against cigarette advertising, was submitted to the board in addition to many other data by both sides. A veritable army of staff from the tobacco industry, advertising agencies, and television stations, including many flown in from overseas, made a united submission for tobacco advertising to continue, using arguments now well known throughout the world.

Legislation-The Antismoking Review Group, a government committee, has examined current legislative, administrative, and publicity measures used by the government and has completed a report recommending additional measures to be taken. An eventual complete ban on advertising in all its forms is under consideration.

Hong Kong Council on Smoking and Health-The government of Hong Kong has approved the setting up of a quasiautonomous permanent Council on Smoking and Health to prepare, propose, coordinate, supervise, and undertake measures against the harmful effects of tobacco.

\section{Discussion}

Most of the general public do not object to stricter measures against smoking, including legislation, once they have been made aware of the risks of tobacco. As the government of Hong Kong launched a broad range of measures simultaneously in 1982 it is hard to assess the relative effects of different factors that contributed to the substantial drop in the number of cigarette smokers from 1982 to 1984. Surveys, however, quote ex-smokers as identifying two main factors that persuaded them to quit-namely, cost and health. Experience from other countries confirms that an increase in tax is a potent method of reducing the number of smokers. Political action, with support, funding, and protection by the government, in a developing Asian country can have striking effects on cigarette smoking and awareness in the community of the dangers of tobacco. The success of the campaign in Hong Kong was due largely to such government action.

Accepted 25 February 1986
It is generally taught that when "sick sinus" is treated by pacemaker life is not only enhanced but substantially prolonged. Is this so and if it is has the news been recognised by life insurance companies or are sick sinus sufferers still loaded?

The survival rate of paced patients with sick sinus syndrome is variously reported, and it is important to note that many early life expectancy studies were only approximations and some did not use cumulative survival analysis. Recently a survival rate for such patients nearly identical to the normal population has been reported and is explained by the authors as being due to the relative absence of other complicating factors in the group in question since a poor prognosis has been found in small groups with other serious diseases.' The life expectancy for unpaced patients with the sick sinus syndrome is also good, ${ }^{2}$ however, and many such patients are paced to improve the quality of life only. This being so, the complications of pacing must be considered, together with the fact that most deaths are attributed to ischaemic heart disease or cerebrovascular embolic events, which are not prevented by ventricular demand pacing. Although most respond well to this pacing mode, it is now suggested that dual chamber pacing may be better for the control of angina and dyspnoea (related to low cardiac output) and may also reduce the incidence of thromboembolic episodes. ${ }^{3}$ These devices, however, are more expensive and require more technical skill in implantation and management.

By and large paced patients tend to pay higher life insurance premiums than normal subjects. Nevertheless, full details relating to the circumstances surrounding an implant are usually sought with particular attention being placed on the nature of the underlying and associated disorders. Normal rates may be obtained in favourable circumstances. - JOHN HORGAN, consultant cardiologist, Dublin.

1 Alt E, Volker $\mathrm{R}$, W'irt/feld AM, et al. Survival and follow up after pacemaker implantation: a comparison of patients with sick sinus svndrome, complete heart block and atrial fibrillation. comparison of patic

2 Shaw DB. Holman RR, Gowers JI. Survival in sinoatrial disorders sick sinus svndrome). Br.Med 7 1980:280:139-41

3 Kaul V. Grigg L. Cardiac pacing in sinoatrial bradyarrhythmias. Clmical Progress in Pacing and Electrophysolog 1985;3:124-32.

Two patients have had complete remission of persistent/recurrent plantar warts during pregnancy. Is this coincidence or a recognised phenomenon?

It is certainly unusual for warts to undergo spontaneous regression during pregnancy; they usually become more florid. Regression of warts and response to treatment depend in part on the ability of the individual to mount a cell mediated immune response against the wart virus (human papilloma virus) infection. Such response is diminished rather than enhanced during pregnancy.-MARY H BUNNEY, consultant dermatologist, Edinburgh. 